\title{
Environmental Performance and Financial Performance of Green Mutual Fund-Evidence from China
}

\author{
Yin Yuan \\ Jinan University, Guangzhou, China \\ Email: y058500@hotmail.com
}

How to cite this paper: Yuan, Y. (2017) Environmental Performance and Financial Performance of Green Mutual FundEvidence from China. Open Journal of Business and Management, 5, 680-698. https://doi.org/10.4236/ojbm.2017.54057

Received: October 10, 2017

Accepted: October 24, 2017

Published: October 27, 2017

Copyright $\odot 2017$ by author and Scientific Research Publishing Inc. This work is licensed under the Creative Commons Attribution International License (CC BY 4.0).

http://creativecommons.org/licenses/by/4.0/

\begin{abstract}
We compared the environmental performance and financial performance between green fund and non-green fund to explore the balance between environmental goals and financial objectives of green funds by in the context of China government's strong advocacy of "developing green finance and setting up green development fund". In this paper, the open-ended active fund with the shareholding ratio of over $75 \%$ is taken as the object of study. By the PSM method, 28 green funds are matched by $1: 5$ to obtain 140 non-green funds. Through the large sample data of 2010-2016, the results show that: 1) the green fund investment portfolio is cleaner than non-green fund. From the long-term environmental performance of the holding enterprises, the green and the non-green fund's environmental performance and financial performance are tested empirically. Fund environmental performance is better than non-green fund. From the perspective of the short-term environmental performance of the holding enterprises, there is no difference between the environmental performance of the green fund and the non-green fund. 2) The excess return of the green fund is higher than that of the non-green fund. In the period of China's economic transformation, green funds not only assume the responsibility of investing in environmental performance of enterprises, but also take into account its financial performance, to achieve a win-win result of low pollution and high yield.
\end{abstract}

\section{Keywords}

Green Fund, Environmental Performance, Financial Performance

\section{Introduction}

China has developed rapidly since the reform and opening up. But due to de- 
forestation and arbitrary emissions, environmental pollution is increasingly serious in China. Only $28 \%$ of the 500 monitored sites in China reported potable water quality, where one third of the water is contaminated and not suitable for drinking, or used as agricultural or other domestic water. In October 2011, the US embassy data showed that the PM2.5 index was more than 300 times, marked "toxic", in Beijing. In order to solve the above problems, according to the Chinese Ministry of Environmental Protection estimates, "thirteen" green industry during the annual investment of at least 2 trillion Yuan, but in the past two years, China's central and local finance can only come out more than 200 billion Yuan Support for environmental protection, energy saving, new energy and other green investment. It is urgent for China to use green financial tools leveraging social capital and accelerate green transformation of China's economics.

It is undoubted that the emergence of green funds provides a viable solution to satisfy needs of funds for the green industry development. The People's Bank of China, the Ministry of Finance and other seven ministries and commissions jointly issued the "Guidance on the construction of green financial system", stressing that the main purpose of building a green financial system is to mobilize and stimulate more social capital into Green industry, and more effectively curb polluting investment on August 31, 2016. The State Council issued the "thirteen" eco-environmental protection plan, clearly putting forward the establishment of market-oriented operation of the various types of green development fund. It took "developing green finance and establishing green fund" as its theme on December 5, 2016.

The Green Fund does not currently have a unified definition. Fernando et al. [1] argue that funds that investors can use to meet double investment goalseconomic goals and environmental goals. Marian et al. [2] pointed out that the Green Fund is considered to be a low-carbon or climate-adaptive investment in companies, projects and financial instruments in areas such as climate change, renewable energy, and clean technology. Green Fund in this article refers to the special energy-saving emission reduction strategy, low-carbon economic development, environmental optimization and transformation projects. Its purpose is to promote the development of energy-saving emission reduction through capital investment. We defines the "green fund" for the open funds' name and investment objectives include "green" "low carbon" and other similar keywords. China's first green fund-HSBC Jinxin low carbon pioneer stock securities investment fund was established in June 2010. In Table 1, open-end funds in the green fund and non-green fund size and quantity showed a growth trend from 2011 to 2016, but the size of the green fund is much smaller than the total size of non-green fund. In 2010, the total size of the green fund was only $0.07 \%$ of the non-green fund. By 2016, the size of the green fund reached 3.89 billion yuan, $0.42 \%$ for the non-green fund size. The reason is that the green fund is set up for a shorter time and the number of green funds is less.

In the background of vigorously promoting the development of green finance 
Table 1. Green Fund and non-green fund size and quantity.

\begin{tabular}{ccccc}
\hline & \multicolumn{2}{c}{ Green Fund } & \multicolumn{2}{c}{ Non-green Fund } \\
\hline Year & Size (billions) & quantity & Size (billions) & quantity \\
\hline 2010 & 1.75 & 3.00 & 2480.00 & 776.00 \\
2011 & 3.16 & 5.00 & 2140.00 & 1010.00 \\
2012 & 2.79 & 6.00 & 2790.00 & 1345.00 \\
2013 & 5.25 & 9.00 & 2990.00 & 1852.00 \\
2014 & 13.40 & 15.00 & 4560.00 & 2328.00 \\
2015 & 50.40 & 36.00 & 8380.00 & 3417.00 \\
2016 & 38.90 & 46.00 & 9080.00 & 5120.00 \\
\hline
\end{tabular}

Data source: http://www.resset.cn/.

and the establishment of green funds, the green fund on the one hand implement its protection of the environment. On the other hand, it is required to achieve the economic goals for investors to create revenue. So, is the green fund taking into account its two goals? This paper presents the following two questions: (1) Is green fund more green than non-green fund? 2) Is the green fund financial performance better than non-green fund?

In this paper, 28 gold funds are matched with 140 funds according to the ratio of 1:5 by the nearest neighbor orientation score matching method. First of all, this paper examines the differences between green fund and non-green fund environmental performance, to test whether the green fund to achieve its environmental goals. Secondly, this paper uses the Carhart four-factor model to measure the financial performance of the fund to test the difference between the financial performance of the green fund and the non-green fund.

The academic contribution of this paper is to enrich the literature of social responsibility institutional investors. Most of the research has focused on the financial performance of socially responsible investment funds, and there are few studies on green funds. However, the green funds are different from those of other institutional investors. For example, the industry the green fund investment in is highly correlated with environmental investment, such as low-carbon, new energy industry. In the context of China's unique, green fund environmental performance is even more important. As the green fund in the country also belongs to the relatively new topic in China, the empirical research about Chinese green funds is almost blank. It is also of great theoretical and practical significance to focus on the investment strategy of green fund, guiding the investment decision of the green investment fund reasonably and promoting the development of green industry.

The remainder of the paper is organized as follows. In Section 2, we review the literature on the environmental performance and financial performance of green mutual funds. In Section 3, we provided 2 hypotheses according to the theory analysis. In Section 4, we describe the sample selection and the variables in the study. In Section 5, we compared the environmental performance and financial 
performance between green funds and conventional funds. In section6, we did a robustness test. We conclude in Section 7.

\section{Literature Review}

\subsection{Green Fund Environmental Objectives}

With the rapid increase in green industry, there triggered more and more academic discussion about green investment funds. Bollen [3] argues that investors may have a multi-attribute utility function that is not only based on the standard risk return, but also contains the investor's values. Green Fund's environmental goals are an important sign of its distinction with traditional funds. It mainly refers to the fund in the construction of the portfolio when the screening. This screening can be roughly divided into two types: negative screening and active screening. Renneboog et al. [4] gave a detailed account of it. The oldest and most basic screening strategies are based on negative screening. These screening refers to practices that exclude specific assets or industries from the portfolio of funds based on environmental protection standards. Typical negative screening can be applied to initial pool of assets, such as excluding alcohol, tobacco, gambling and defense industries or poorly performing companies from the S \& P 500 stock. After a negative screening, build a portfolio by financial and quantitative analysis. When these companies' environmental issues are below a certain threshold, the green fund can only exclude these companies. The use of negative screening funds such as the first social responsibility fund-the Pioneer Fund, its opposition to alcohol and tobacco [5]. Kinder [6] and the World Economic Fund found that the "Pax World Fund", launched in 1971, screened military inventories during the Vietnam War. Active screening means that the green fund is actively looking for environmental performance or investing in renewable energy use, recycling companies to invest. Active screening is often combined with the "best of breed" approach. Funds will rank enterprises in accordance with environmental performance and select the best environmental performance of enterprises to invest.

The impact of environmental screening on fund performance is contradictory. JD Diltz [7] found that environmental screening had no significant impact on fund market returns by examining the daily returns from January 1, 1989 to December 31, 1991. Guerard [8] also found no significant difference between them by examining the financial performance of 950 screened companies and 1300 unscreened companies during 1987-1994. Statman and Glushkov [9] also found positive relationships between positive screening and portfolio performance, but negative screening reduced the performance of the portfolio. JE Humphrey [10] found that positive or negative screening had little impact on market returns by studying the positive, negative and total screening effect of the Australian market on fund risk and performance. However, active screening can effectively reduce the risk of the fund, while the negative screening will increase the risk of the fund, thereby reducing the diversity of fund selection. Borgers et al. [11], who show that funds with higher exposure to sin stocks display higher risk-adjusted 
performance.

\subsection{Green Fund Financial Performance}

The current opinions on whether social responsibility funds and green funds are able to achieve good financial performance are not consistent. On the one hand, companies that invest in environmental performance are likely to reduce their investment opportunities [12] [13] and increase regulatory costs [14]. On the other hand, green funds invest in environmentally friendly companies are more likely to achieve sustainable returns and long-term prospects for development. A large number of literature points out that the positive correlation between environmental performance and financial performance, such as Hamilton [15], who examines the impact of news on corporate environmental issues through incidental research and finds that the use of toxic chemicals in the United States had significant negative impact on stock prices. Similarly, Klassen and Mc Laughlin [16] found that the company received positive returns after obtaining environmental performance awards and showed significant negative returns after the environmental crisis.

Some scholars have compared the Green Fund with the market returns of other funds. Climent and Soriano [17] compared the financial performance and risk sensitivity of the US Green Investment Fund and other social responsibility funds and found that the Green Fund's financial performance was worse than the traditional social responsibility fund during the 1987-1999 period. However, in 2001-2009, there was no significant difference between the green fund's adjusted returns and other social responsibility funds. Munoz et al. [1] have also found that green funds are not significantly different from non-green funds by studying the financial performance and management capabilities of green investment firms in the US and Europe. As mentioned earlier, in the comparative study of social responsibility funds and traditional investment funds found that the it is not contradictory between ecological responsibility and profitability of funds. The vast majority of studies have found that there is no significant difference in performance between social responsibility funds and traditional investment funds [3]. But Silva and Cortez [18] found that the green fund's economic performance is often lower than the industry benchmark value by studying the US and European green funds.

\section{Theoretical Analysis and Research Hypothesis}

From the macroeconomic impact of the macroeconomic policy, in the context of China's current system, the environmental performance of poor enterprises is facing greater legitimacy pressure [19]. The penalties incurred by enterprises due to environmental pollution or the resulting cleanliness costs will have a negative impact on the financial performance of the business; and good environmental performance can attract more government policy support. Li Wenjing and $\mathrm{Lu}$ xiaoyan [20] found that enterprises with better environmental performance have 
higher bank loan growth rates and lower loan costs. From the theory of risk and income, institutional investors will choose the same income, but less risky projects. The good environmental performance of a business can be seen as a way to reduce risk [21] [22]. For example, traditional investors have been underestimating the possibility of oil companies suffering from oil spills. The oil company's stock price decline due to oil spill will be the rate of return on conventional portfolio stocks, but the socially responsible portfolio is immune from the avoidance of investment and the oil industry. Spicer [23] also found that companies with good pollution control records have higher margins, lower systemic and total risks by measuring the corporate environmental reputation with the Council on Economic Priorities. Dowell et al. [24] found that companies with stricter environmental standards have higher market value. Rennings et al. [25] claim that the design of the environmental management and audit program plays a key role in environmental and financial performance. In addition, Darnall et al. [26] argue that the introduction of a comprehensive environmental management system can create potential business value. $\mathrm{Li}$ Wenjing and $\mathrm{Lu}$ Xiaoyan [20] also found that institutional investors to invest in environmental performance of the enterprise are more likely to get excess returns. Based on the above analysis, the green fund in the choice of investment objects, will be more concerned about the environmental performance of investment objects, more investment in environmental performance of good stocks. This paper makes the following assumptions:

H1: Environmental performance of green fund is better than non-green fund.

Is the green fund outperforming the regular fund? At present, there is no consensus on the academic community.

On the one hand, based on the theory of portfolio, environmental screening narrows the investment area, resulting in the green fund failing to take the optimal portfolio. For traditional funds, there is no industry limit, they will not miss the opportunities brought about by the cyclical nature of the financial market [27] [28]. In addition, the cost structure between green funds and other funds is also different. The regular fund has only one overall goal, i.e., the highest rate of return at a specific risk level. But the green fund in the pursuit of high return before the first to ensure that they invest in enterprises to meet the environmental criteria for the choice of funds. In order to cover the costs associated with environmental screening and monitoring, the Green Fund will assume higher management costs, which will further reduce the net return on green funds. Finally, due to the emphasis on non-economic performance, the Green Fund may have higher agency costs than traditional funds. Its screening and monitoring process may disrupt managers from the important task of creating returns for investors.

On the other hand, the financial performance of the Green Fund may be superior to other funds in the long term, as financial markets underestimate social responsibility in the short term [4]. First, short-sightedness and profit maximi- 
zation may pose a risk of corporate social responsibility. Second, in the case of consumers attach great importance to social responsibility, corporate social responsibility can bring competitive advantage to the enterprise [27] [28]. Third, as mentioned earlier, good environmental performance can provide enterprises with higher management quality and reputation, faster cash flow and lower transaction costs, thereby boosting corporate value [13] [24] [26]. So we make the following assumptions:

$\mathrm{H} 2$ : There is no significant difference in market excess returns between green funds and conventional funds.

\section{Sample Selection and Model Building}

\subsection{Sample Selection}

The green fund, which is defined in this paper, is the open funds whose name or investment standards including key words of "environmental protection", "green", "low carbon", "sustainable", "new energy", "low carbon", “ecology" and "environment". Because the first set of green funds-HSBC Jinxin low carbon pioneer stock securities investment fund was established in June 2010, so this sample period covers the period of 2010 to 2016 . Besides, the fund holding ratio is greater than $75 \%$. The funds included are active funds, that is, filter out the passive index funds. We choose all of China's open-end fund from 2010 to 2016 screening out the proportion of less than 0.75 or index funds to get 1051 funds, including 1023 non-green funds, 28 green funds. This sample is the matching sample of this article.

The size of the fund, age, type of investment, monthly rate of return data from the Risi Financial Research Database (RESSET). Rui Si database founded by the Beijing JuyuanRui Si Data Technology Co., Ltd., covering stocks, foreign exchange, bonds, futures, funds, macro statistics, industry statistics and other data. Enterprise industry data from the CSMAR database, environmental performance data from the annual report of the enterprise manual collection.

\subsection{Variable Construction}

The research variables include fund environmental performance, fund financial performance, fund size, fund age, fund investment type, enterprise industry attribute, enterprise sewage charges, enterprise environmental investment, riskfree interest rate, market factors, scale factors, value factors, and momentum factors (Table 2).

\subsubsection{Fund Environmental Performance Evaluation}

This paper draws on the practice of Ghoul and Karoui [29], builds the fund's environmental performance according to the environmental performance of the fund held by the fund:

$$
E P_{1}=\sum_{i=1}^{N_{t, i}} w_{i, j, t} * E P_{i, t}
$$


Table 2. Research variable definition Table.

\begin{tabular}{|c|c|c|}
\hline Variable name & $\begin{array}{l}\text { Variable } \\
\text { symbol }\end{array}$ & Variable definitions \\
\hline Fund grouping & Green & $\begin{array}{l}\text { Fund classification, if the green fund is assigned to } 1 \text {, } \\
\text { otherwise assigned to } 0\end{array}$ \\
\hline \multirow{3}{*}{$\begin{array}{c}\text { Fund } \\
\text { environmental } \\
\text { performance }\end{array}$} & EP1 & $\begin{array}{l}\text { According to the enterprise industry attributes calculated fund } \\
\text { environmental performance }\end{array}$ \\
\hline & EP2 & $\begin{array}{c}\text { According to the enterprise sewage charges calculated fund } \\
\text { environmental performance }\end{array}$ \\
\hline & EP3 & $\begin{array}{l}\text { According to the enterprise environmental investment } \\
\text { calculation of the fund environmental performance }\end{array}$ \\
\hline \multirow{2}{*}{$\begin{array}{l}\text { Fund financial } \\
\text { performance }\end{array}$} & $\mathrm{Yg}$ & Green Fund Group Monthly average market excess returns \\
\hline & $\mathrm{Yq}$ & Non-green fund group average monthly excess returns \\
\hline Fund size & Formsize & Fund formation size \\
\hline Fund age & age & The age of fund at the end of 2016 \\
\hline Fund invest type & Investtype & $\begin{array}{l}\text { Fund investment type classification, } 0 \text { for the value type, } \\
1 \text { for the balance, } 2 \text { for the growth }\end{array}$ \\
\hline Risk-free rate & $\mathrm{Rf}$ & "Three-month central bank bills" coupon rate \\
\hline Market factors & MKT & $\begin{array}{l}\text { CSI } 300 \text { Index monthly rate of return and the average } \\
\text { monthly risk-free rate of difference }\end{array}$ \\
\hline Scale factor & SMB & $\begin{array}{l}\text { The difference between the monthly rate of return of } \\
\text { small-scale companies and large-scale companies }\end{array}$ \\
\hline Value factor & HML & $\begin{array}{l}\text { High book market value than the stock and low book value } \\
\text { than the stock monthly rate of return difference }\end{array}$ \\
\hline Momentum factor & UMD & Monthly momentum effect \\
\hline \multirow{3}{*}{$\begin{array}{c}\text { Enterprise } \\
\text { environmental } \\
\text { performance }\end{array}$} & indu & $\begin{array}{l}\text { Enterprise industry attributes, heavily polluting industries } 1 \text {, } \\
\text { non-polluting industries } 0\end{array}$ \\
\hline & sewage & Log (enterprise sewage +1$)$ \\
\hline & epi & $\log ($ enterprise environmental protection investment +1 ) \\
\hline
\end{tabular}

where $w_{i, j, t}$ represents the share of stocki at the end of year $t$ in fund $j ; N_{j, t}$ represents the number of shares held by fund $j$ at the end of year $t, E P_{i, t}$ represents environmental performance of stock $i$ at the end of the year.

As there is not unified environmental performance score in China, we try to evaluate the environmental performance of enterprises according to government regulations or previous literature, and then calculated according to formula (1) to obtain the fund environmental performance.

1) Enterprise industry-weighted fund environmental performance

In this paper, the company's environmental performance measurement first reference to the 2008 published "listed companies environmental verification industry classification management list" and the China Securities Regulatory Commission 2012 edition of "listed companies industry classification guidelines", which divided enterprises into heavily polluting industries and non-polluting industries. The "List of Management Regulations on Environmental Protection Industry of Listed Companies" states that the heavily polluting industries include thermal power, steel, cement, electrolytic aluminum, coal, metallurgy, building materials, mining, chemical, petrochemical, pharmaceutical, light industry (brewing, paper making, Textile and tanning. The industry attribute can 
be used as the initial screening of enterprise environmental performance. According to the Formula (1), fund environmental performance $E P_{1}$ :

$$
E P_{1}=\sum_{i=1}^{N_{t, i}} w_{i, j, t} * \operatorname{Ind} u_{i, t}
$$

where $w_{i, j, t}$ represents the share of stock $i$ at the end of year $t$ in fund $j N_{i, t}$ represents the number of shares held by fund $j$ at the end of year $t, \operatorname{Indu}_{i, t}$ represents stock $i$ at the end of the year $t$ industry, 1 if it is in heavy polluting industry, else is 0 .

2) Environmental performance of the enterprise's environmental protection investment

Second, based on Li Wenjing and Lu Xiaoyan [20], we use the environmental protection-related debit increase in construction from the company's annual report to measure the company's environmental long-term performance, including environmental management, sewage treatment, environmental design and energy conservation, waste recycling.

According to the Formula (1), fund environmental performance $E P_{2}$ :

$$
E P_{2}=\sum_{i=1}^{N_{t, i}} w_{i, j, t} * e p i_{i, t}
$$

where $w_{i, j, t}$ represents the share of stock $i$ at the end of year $t$ in fund $j ; N_{j, t}$ represents the number of shares held by fund $j$ at the end of year $t, e p i_{i, t}$ represents the expenditure of stock $i$ at the end of the year $t$.

3) Corporate emissions charges weighted fund environmental performance

According to the Regulations of the Chinese State Council on the Administration of the Collection and Use of Sewage Charge (Chinese State Council Decree No. 369), it is necessary for the units and individual industrial and commercial households that pull directly pollutants into the environment to pay the sewage charges. Sewage charges include sewage charges, solid waste and hazardous waste discharge charges, excessive noise pollution charges. Sewage charges are measured according to the type of pollutants and the amount of pollution equivalent and each pollution equivalent is 0.7 Yuan. Enterprise sewage charges can be used as short-term environmental performance of enterprises, which is objective to reflect the level of pollution.

According to the Formula (1), fund environmental performance $E P_{2}$

$$
E P_{3}=\sum_{i=1}^{N_{t, i}} w_{i, j, t} * \text { sewage }_{i, t}
$$

where $w_{i, j t}$ represents the share of stock $i$ at the end of year $t$ in fund $j N_{j, t}$ represents the number of shares held by fund $j$ at the end of year $t$, sewage represents the sewage charges of stock $i$ at the end of the year $t$.

\subsubsection{Fund Financial Performance}

Based on Carhart [30], this paper uses the four-factor model to measure the financial performance of the fund. The mathematical expression of the four-factor 
model is as follows:

$$
R_{t}-R_{f, t}=\partial+\beta_{M K T}\left(r_{t}^{m}-r_{f, t}\right)+\beta_{S M B} r_{t}^{s m b}+\beta_{H M L} r_{t}^{h m l}+\beta_{U M D} r_{t}^{u m d}+\eta_{t}
$$

where $R_{t}$ is the average yield of fund at month $t$, which means $R_{f, t}$ average riskfree rate of return in month $t, R_{m}$ represents the average yield of the market portfolio, $\partial$ representing the excess return on the fund's investment, $\eta_{t}$ indicating heterogeneous gains; $r_{t}^{s m b}, r_{t}^{h m l}, r_{t}^{u m d}$ representing market factors, scale factors and momentum factors,.

\subsubsection{Matching Variables}

Based on Mallin et al. [31] and Gregory et al. [32], this paper chooses the size of the fund, the date of fund establishment, and the type of fund investment as matching criteria. The matching method can eliminate the characteristics of the green fund to a certain extent.

First, the size of the fund. Mallin et al. [31] pointed out that the size of the fund has a significant impact on the financial performance of the Green Fund. Gregory et al. [32] argue that the Green Fund is more willing to invest in smaller companies.

Second, the fund age. Fund age is the age of the fund as of December 31.

Third, the type of fund investment. Gregory et al. [32] pointed out that even the same size and age of funds, the type of investment is different. Luther et al. [33] pointed out that social responsibility funds are more inclined to choose less diverse companies.

\subsection{Test Method-Propensity Score Matching}

First, we enter the PSM first stage regression. We use the following log it regression model (model 1) to calculate the propensity score to pair.

$$
\operatorname{Logit}\left(\text { green }_{i}\right)=\partial_{0}+\partial_{1} \text { Formsz }_{i}+\partial_{2} \text { Age }_{i}+\partial_{3} \text { Invsettype }_{i}+\varepsilon_{i}
$$

Secondly, we calculate the average treatment effect, referred to as "ATT": The theoretical framework of the tendency analysis is the "counterfactual inference model", which is mainly used to solve the causal inference problem of sample selectivity deviation. Suppose that each individual i receiving an intervention has two potential outcomes $\left(Y_{0 i}, Y_{1 i}\right)$ that represent the potential results that are not intervened and intervened, respectively. Let $D_{i}=0$ indicate that the sample has not been intervened, $D_{i}=1$ indicates that the sample is intervened, The counterfactual framework model is:

$$
Y_{i}=D_{i} Y_{1 i}+\left(1-D_{i}\right) Y_{0 i}=Y_{0 i}+\left(Y_{1 i}-Y_{0 i}\right)
$$

where $\left(Y_{1 i}-Y_{0 i}\right)$ is the processing effect of $i$. Because it is a random variable, so we are concerned about its expectations, that is "ATT":

$$
\operatorname{ATT}=E\left(Y_{1 i}-Y_{0 i}\right)=E\left(Y_{1 i}-Y_{0 i} \mid D_{i}=1\right)
$$

Thirdly, this paper takes $k$ nearest neighbor matching to match. Since the propensity score calculated by model (5) is a continuous variable, we cannot directly 
match exactly the same tendency score to calculate ATT. In this paper, we take k nearest neighbor matching to match.

Let $P_{i}$ and $P_{j}$ be the inclination values of the intervention group and the members of the control group, respectively. I0 and I1 are the set of control group and intervention group members respectively. The nearest neighbor 1:n matches means that for each intervention member $i, \mathrm{n}$ members are found to fall $d\left(P_{i}\right)$, $d\left(P_{i}\right)$ is the distance between the intervention group and the control group:

$$
d\left(P_{i}\right)=\min \left\|P_{i}-P_{j}\right\|, j \in I_{0}
$$

When the distance between the intervention group and the control group is less than $d\left(P_{i}\right)$, the control group is regarded as the successful matching object of the intervention group. At this point we can calculate the estimated value of ATT:

$$
\tau=\frac{1}{N^{T}} \sum_{i \in T} Y_{i}^{T}-\frac{1}{N^{C}} \sum_{i \in C} w_{j} Y_{j}^{C}
$$

ATT variance is:

$$
\operatorname{Var}(\tau)=\frac{1}{N^{T}} \operatorname{Var}\left(Y_{i}^{T}\right)+\frac{1}{\left(N^{C}\right)^{2}}\left(w_{j}\right)^{2} \operatorname{Var}\left(Y_{j}^{C}\right)
$$

The difference between ATT and the variance is obtained, and the difference between the matching group and the control group can be obtained.

\section{Empirical Results and Analysis}

\subsection{Green Fund Environmental Performance}

First, we uses the logit model to estimate propensity score. In Table 3, we can see whether it is green fund is not significant correlated with the investment type, and positively correlated with the initial size of the fund at the $5 \%$ significance level, And negatively correlated with fund age the significance level of 5\% we use 28 green fund to match 140 non-green fund with the ratio of 1: 5. Table 4 shows the change in sample characteristics before and after matching. The size of the green fund and the non-green fund before the match was $37.2 \%$, positive at the $10 \%$ significance level. After the match the deviation rate dropped to $-0.6 \%$, which was statistically no longer significant. The age of the fund before the match was $-33.4 \%$, which was significantly negative at the $10 \%$ significance level. After the match the deviation rate dropped to $-0.8 \%$, which was statistically no longer significant. The investment type was $13.6 \%$ before matching, and decreased to $-4.6 \%$ after matching, which was not statistically significant. There was no significant difference in the scale, age and investment type between the green fund and the non-green fund after matching.

Figure 1 shows the nuclear density function diagram of the green fund group and non-green fund group before and after matching. Obviously, there is a significant difference between the green fund and the non-green fund before matching. After matching, the nuclear density function graph between the two 

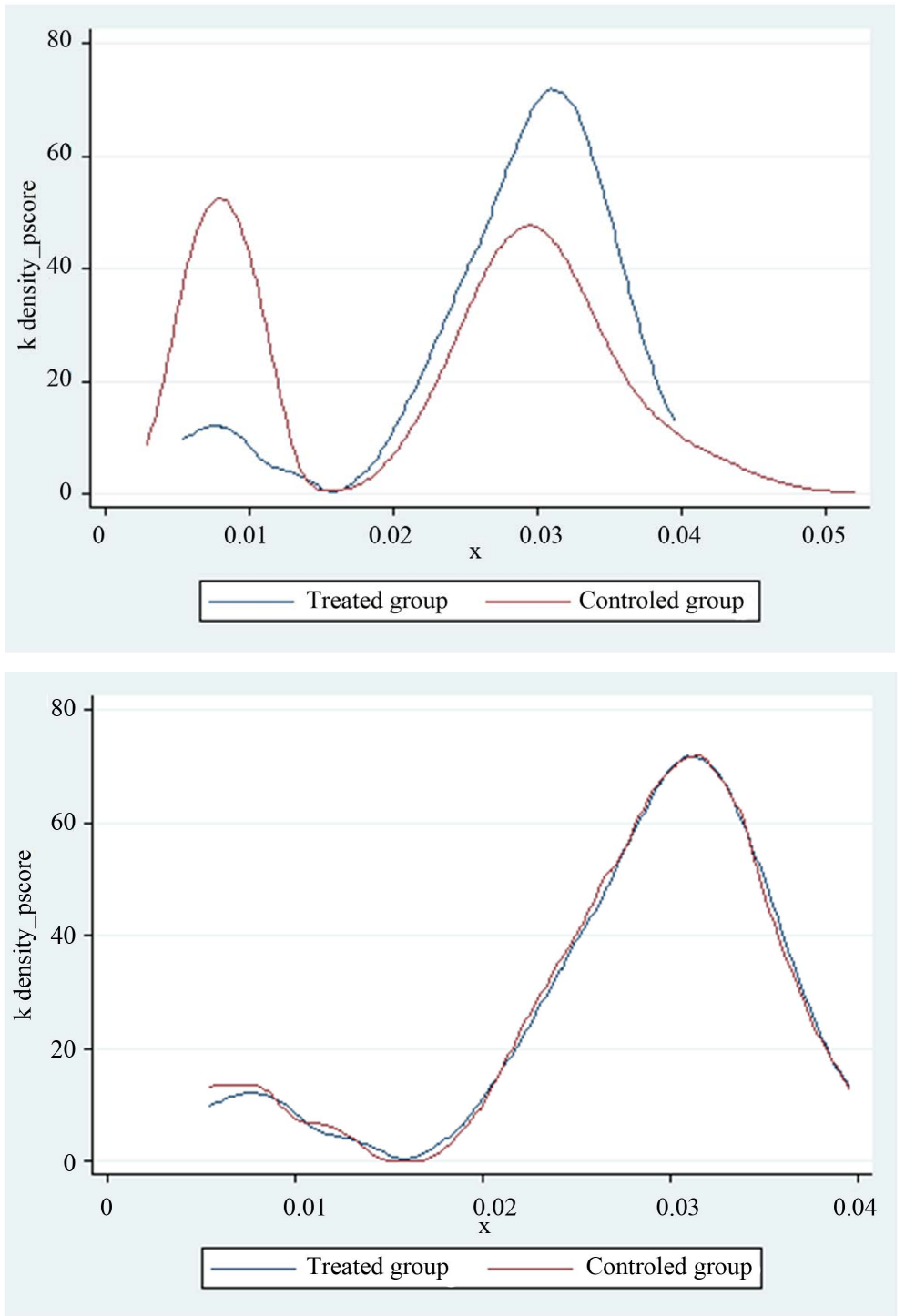

Figure 1. The kernel density function before and after matching. Data source: Data for this article.

Table 3. Logit model estimation results.

\begin{tabular}{cc}
\hline & green \\
\hline cons & $-9.167^{* * *}$ \\
lnformsize & $(-3.030)$ \\
& $0.306^{* *}$ \\
age & $(2.080)$ \\
& $-0.039^{* *}$ \\
Investtype 1 & $(-2.020)$ \\
& 0.345 \\
Investtype 2 & $(0.72)$ \\
& 0.103 \\
\end{tabular}

Data source: Data for this article. 
groups becomes very close, indicating that the characteristics of the green fund and the non-green fund become similar after matching.

Table 5 shows the difference between the green fund and the matching environmental performance. It can be seen that after matching the difference between the two is -0.0373 at $5 \%$ of the significance level, indicating that the green fund than non-green fund in the industry cleaner. The difference between the green fund and the non-green fund's environmental performance, which is measured by the enterprise's sewage charges, is not statistically significant, indicating that the green fund does not care about the short-term environmental performance of the enterprise. The difference between the green fund and the non-green fund environmental performance measured by the environmental protection investment is 2.001 , which is significantly positive at the $5 \%$ significance level. This shows that the green fund not only chose a clean industry, but also chose a better long-term environmental performance. The Green Fund cares corporates' long-term environmental improvement, which is consistent with Li Wenjing and Lu Xiaoyan [20].

\subsection{Green Fund Financial Performance}

The fund yield data for this paper are the monthly sequence values for a total of 78 months from July 2010 to December 2016. It can be seen that the average

Table 4. Comparison of sample characteristics before and after matching.

\begin{tabular}{|c|c|c|c|c|c|c|}
\hline \multirow{2}{*}{ Variable } & \multirow{2}{*}{ Sample } & \multicolumn{2}{|c|}{ Mean } & \multirow{2}{*}{ Bias $\%$} & \multirow{2}{*}{ Decrease\% } & \multirow{2}{*}{ T test } \\
\hline & & Treated & Controlled & & & \\
\hline \multirow[t]{2}{*}{ lnformsize } & Before matching & 20.74 & 20.25 & 37.2 & \multirow[b]{2}{*}{98.3} & $1.72^{*}$ \\
\hline & After matching & 20.74 & 20.75 & -0.6 & & -0.14 \\
\hline \multirow[t]{2}{*}{ age } & Before matching & 0.853 & 1.041 & -33.4 & \multirow{2}{*}{97.6} & $-1.72^{\star}$ \\
\hline & After matching & 0.853 & 0.858 & -0.8 & & -0.09 \\
\hline \multirow[t]{2}{*}{ Investtype } & Before matching & 0.928 & 0.842 & 13.6 & \multirow{2}{*}{66.6} & 0.69 \\
\hline & After matching & 0.928 & 0.957 & -4.6 & & -0.17 \\
\hline
\end{tabular}

Data source: Data for this article.

Table 5. ATT results.

\begin{tabular}{ccccccc}
\hline Variable & Sample & Treated & Controlled & difference & SD & T score \\
\hline EP1 & Before matching & 0.241 & 0.268 & -0.0269 & 0.0207 & -1.3 \\
& ATT & 0.241 & 0.278 & -0.0373 & 0.0173 & -2.15 \\
EP3 & Before matching & 11.56 & 11.57 & -0.0182 & 0.575 & -0.03 \\
& ATT & 11.56 & 11.64 & -0.0783 & 0.59 & -0.13 \\
EP2 & Before matching & 41.73 & 40.52 & 1.207 & 0.839 & 1.44 \\
& ATT & 41.73 & 39.72 & 2.001 & 0.852 & 2.35 \\
\hline
\end{tabular}

Data source: data for this article. 
yield of green funds is higher than non-green fund in Table 6 in numerical.

Due to the time series data, we first do unit root test, see Table 7 . The test shows that the time series are stable.

Table 8 lists the regression results for the four-factor model. From the table we can see that the green fund intercept item is 0.0043 , but it is not statistically significant, that is, the green fund exceeds the market average return, but not significant. The fund risk factor (MKT) of the green fund is 0.7383 , which is positive at the $1 \%$ significance level, indicating that the green fund has a significant positive correlation with the overall market trend, and the volatility is less than the market. The value of the green fund $(\mathrm{hml})$ is -0.4710 , negative at the $1 \%$ significance level, indicating that the investment performance of the green fund is mostly affected by the trend of high growth stocks. The momentum factor (umd) of the green fund is 0.1558 , which is positive at the $1 \%$ significance level, indicating that the green fund has a significant positive correlation with the high yield stock.

Table 6. Four-factor model descriptive statistics.

\begin{tabular}{cccccc}
\hline Variable & Sample & Means & SD & Min & Max \\
\hline yg & 78 & 0.0089 & 0.0676 & -0.2330 & 0.1910 \\
yc & 78 & 0.0054 & 0.0699 & -0.2430 & 0.1800 \\
$\mathrm{smb}$ & 78 & 0.0155 & 0.0460 & -0.1720 & 0.1960 \\
$\mathrm{hml}$ & 78 & -0.0014 & 0.0392 & -0.1570 & 0.1510 \\
$\mathrm{umd}$ & 78 & -0.0137 & 0.0668 & -0.2170 & 0.1480 \\
$\mathrm{rf}$ & 78 & 0.0035 & 0.0008 & 0.0021 & 0.0051 \\
\hline
\end{tabular}

Data source: data for this article.

Table 7. Unit root test.

\begin{tabular}{cccccc}
\hline & ADF & $1 \%$ Critical value & PP & $1 \%$ Critical value & conclusion \\
\hline yg & -7.44 & -3.542 & -7.381 & -3.542 & sTable \\
yc & -7.475 & -3.542 & -7.394 & -3.542 & sTable \\
mkt & -7.353 & -3.542 & -7.282 & -3.542 & sTable \\
smb & -8.633 & -3.542 & -8.652 & -3.542 & sTable \\
hml & -9.934 & -3.542 & -10.067 & -3.542 & sTable \\
umd & -8.771 & -3.542 & -8.779 & -3.542 & sTable \\
\hline
\end{tabular}

Data source: data for this article.

Table 8. Four-factor model regression results.

\begin{tabular}{ccccccc}
\hline & $\partial$ & $\mathrm{mkt}$ & $\mathrm{smb}$ & $\mathrm{hml}$ & $\mathrm{umd}$ & $\mathrm{R} 2$ \\
\hline $\mathrm{yg}$ & 0.0043 & $0.7383^{\star * *}$ & 0.0939 & $-0.4710^{\star * *}$ & $0.1558^{\star * *}$ & 0.896 \\
$\mathrm{yc}$ & -0.0017 & $0.8339^{\star * *}$ & $0.1468^{\star * *}$ & $-0.3362^{\star * *}$ & $0.0603^{\star * *}$ & 0.967 \\
yq-yc & $0.0054^{\star * *}$ & -0.0956 & -0.0529 & -0.1348 & $0.0955^{\star * *}$ & -0.071 \\
\hline
\end{tabular}

${ }^{*} \mathrm{p}<0.1,{ }^{* *} \mathrm{p}<0.05,{ }^{* *} \mathrm{p}<0.01$. Data source: data for this article. 
Non-green intercept item is -0.0017 , but it is not statistically significant, that is non-green fund is below the average market returns, but this difference is not significant. The non-green fund market risk factor (MKT) is 0.8339 , which is positive at the significant level, indicating that the green fund has a significant positive correlation with the overall market trend, and its volatility is less than the market. The Green Fund size factor (SMB) is 0.1468 , which is positive at a1\% significance level, indicating that non-green funds are more susceptible to small-cap stocks. Non-green fund value factor $(\mathrm{hml})$ is -0.3362 , negative at $1 \%$ level of significance, indicating that non-green fund investment performance mostly by the impact of high-growth stocks. The non-green fund's momentum factor (umd) was 0.0603 , which was positive at the $1 \%$ significance level, indicating that the non-green fund as a whole was positively correlated with the trend of high-yield stocks.

Further using Suest test method, we compare the green fund and non-green fund four factors model coefficient difference. We can see that the difference between the green fund and the non-green intercept is 0.0054 , which is positive at the $1 \%$ significance level, indicating that the green fund's market returns is higher than the non-green fund, that is, the financial performance of the green fund better than non-green funds. In addition, there is no significant difference between the green fund and the non-green fund in the market factors, the scale factor and the value factor, which shows that there is no significant difference between the green fund and the non-green fund in the above factors. In the momentum factor, the green fund is higher than the non-green fund 0.0955, positive at the $1 \%$ significance level, indicating that the green fund is more likely to be affected by the high-yield stock trend than the non-green fund.

\section{Robustness Test}

\subsection{Green Fund Environmental Performance}

We use nuclear matching and radius matching method to do robust test. as shown in Table 9 and Table 10, it was found that the green fund not only selected the industry's industry, but also chose the enterprises with better long-term environmental performance. The results are consistent with the previous text.

\subsection{Green Fund Financial Performance}

We use the Jensen index and the three-factor model to test the financial performance of funds, as shown in Table 11 and Table 12. The results show that the difference between the green fund and the non-green intercept term is still positive at the $1 \%$ significance level, indicating that the green fund's market excess returns are higher than non-green funds. The results are robust.

\section{Conclusion}

This paper compares the environmental performance and financial performance 
Table 9. Core match results.

\begin{tabular}{ccccccc}
\hline variable & sample & Treated & Controlled & Difference & SD & T test \\
\hline EP1 & before matching & 0.241 & 0.268 & -0.0269 & 0.0207 & -1.300 \\
& ATT & 0.241 & 0.268 & -0.0271 & 0.0152 & -1.790 \\
EP3 & before matching & 11.56 & 11.57 & -0.0182 & 0.575 & -0.0300 \\
& ATT & 11.56 & 11.58 & -0.0185 & 0.509 & -0.0400 \\
EP2 & before matching & 41.73 & 40.52 & 1.207 & 0.839 & 1.440 \\
& ATT & 41.73 & 40.53 & 1.199 & 0.701 & 1.710 \\
\hline
\end{tabular}

Data source: data for this article.

Table 10. Radius match results.

\begin{tabular}{ccccccc}
\hline variable & sample & Treated & Controlled & Difference & SD & T test \\
\hline EP1 & before matching & 0.241 & 0.268 & -0.0269 & 0.0207 & -1.3 \\
& ATT & 0.241 & 0.273 & -0.0325 & 0.0157 & -2.07 \\
EP3 & before matching & 11.56 & 11.57 & -0.0182 & 0.575 & -0.03 \\
& ATT & 11.56 & 11.41 & 0.148 & 0.522 & 0.28 \\
EP2 & before matching & 41.73 & 40.52 & 1.207 & 0.839 & 1.44 \\
& ATT & 41.73 & 40.26 & 1.467 & 0.722 & 2.03 \\
\hline
\end{tabular}

Data source: data for this article.

Table 11. Jensen index return results.

\begin{tabular}{cccc}
\hline & $\partial$ & $\mathrm{mkt}$ & $\mathrm{R} 2$ \\
\hline $\mathrm{yg}$ & 0.0039 & $0.8113^{* * *}$ & 0.785 \\
yc & 0.0004 & $0.8308^{* * *}$ & 0.844 \\
yq-yc & $0.0035^{*}$ & -0.0195 & -0.059 \\
\hline
\end{tabular}

${ }^{*} \mathrm{p}<0.1,{ }^{* *} \mathrm{p}<0.05,{ }^{* *} \mathrm{p}<0.01$. Data source: Data for this article.

Table 12. Three-factor model regression results.

\begin{tabular}{cccccc}
\hline & $\partial$ & $\mathrm{mkt}$ & $\mathrm{smb}$ & $\mathrm{hml}$ & $\mathrm{R} 2$ \\
\hline $\mathrm{yg}$ & 0.0025 & $0.7565^{\star * *}$ & 0.0706 & $-0.4592^{* * *}$ & 0.873 \\
yc & -0.0022 & $0.7649^{\star * *}$ & $0.1580^{* *}$ & $-0.4019^{* * *}$ & 0.946 \\
yq-yc & $0.0047^{\star *}$ & -0.0084 & -0.0874 & -0.0573 & -0.073 \\
\hline
\end{tabular}

${ }^{*} p<0.1,{ }^{* *} p<0.05,{ }^{* *} p<0.01$. Data source: Data for this article.

of 28 green funds and 140 matching non-green funds in 2010-2016, and finds that:

1) Green fund portfolio industry configuration is cleaner than non-green fund. From the long-term environmental performance of holding companies, green fund environmental performance is better than non-green fund. This shows that the Green Fund not only invested in the cleaner industry, and actively 
concerned about the enterprises' long-term environmental performance.

2) The market excess return of green fund is higher than non-green fund, indicating that the green fund financial performance is superior to non-green fund. In addition, there is no significant difference between the green fund and the non-green fund in the market factors, the scale factor and the value factor, which shows that there is no significant difference between the green fund and the non-green fund in the above risks.

The findings of this paper have the following two aspects contributions: first, the findings of this article enriched the literatures of green funds from the Chinese market on the green fund research; second, this is the first empirical study of Chinese green funds, providing the evidence that Chinese green fund is much greener than non-green fund and achieves higher market returns.

\section{References}

[1] Muñoz, F., Vargas, M. and Marco, I. (2014) Environmental Mutual Funds: Financial Performance and Managerial Abilities. Journal of Business Ethics, 124, 551-569. https://doi.org/10.1007/s10551-013-1893-x

[2] Voica, M.C., Panait, M. and Radulescu, I. (2015) Green investments-Between Necessity, Fiscal Constraints and Profit. Procedia Economics \& Finance, 22, 72-79. https://doi.org/10.1016/S2212-5671(15)00228-2

[3] Bollen, N.P.B. (2007) Mutual Fund Attributes and Investor Behavior. Journal of Financial \& Quantitative Analysis, 42, 683-708.

[4] Renneboog, L., Horst, J.T. and Zhang, C. (2008) Socially Responsible Investments: Institutional Aspects, Performance, and Investor Behavior. Journal of Banking \& Finance, 32, 1723-1742.

[5] Schwartz, M.S. (2003) The "Ethics" of Ethical Investing. Journal of Business Ethics, 43, 195-213. https://doi.org/10.1023/A:1022933912939

[6] Kinder, P.D. and Domini, A.L. (1997) Social Screening: Paradigms Old and New. The Journal of Investing, 6, 12-19. https://doi.org/10.3905/joi.1997.408443

[7] Diltz, J.D. (1995) Does Social Screening Affect Portfolio Performance? Journal of Investing, 4, 64-69. https://doi.org/10.3905/joi.4.1.64

[8] Guerard, J. (1996) Is There a Cost to Being Socially Responsible in Investing? Vantage Global Investors, 16, 475-490.

[9] Statman, M. and Glushkov, D. (2009) The Wages of Social Responsibility. Financial Analysts Journal, 65, 33-46. https://doi.org/10.2469/faj.v65.n4.5

[10] Humphrey, J.E. and Lee, D.D. (2011) Australian Socially Responsible Funds: Performance, Risk and Screening Intensity. Journal of Business Ethics, 102, 519-535. https://doi.org/10.1007/s10551-011-0836-7

[11] Borgers, A., Derwall, J., Koedijk, K. and Ter Horst, J. (2015) Do Social Factors Influence Investment Behavior and Performance? Evidence from Mutual Fund Holdings. Journal of Banking and Finance, 60, 112-126. https://doi.org/10.1016/j.jbankfin.2015.07.001

[12] Geczy, C., Stambaugh, R.F. and Levin, D. (2005) Investing in Socially Responsible Mutual Funds. SSRN Electronic Journal, 1-47.

[13] Renneboog, L., Horst, J.T. and Zhang, C. (2008) The Price of Ethics and Stakeholder Governance: The Performance of Socially Responsible Mutual Funds. Journal of Corporate Finance, 14, 302-322. 
[14] Bauer, R., Koedijk, K. and Otten, R. (2005) International Evidence on Ethical Mutual Fund Performance and Investment Style. Journal of Banking \& Finance, 29, 1751-1767.

[15] Hamilton, J.T. (1995) Pollution as News: Media and Stock Market Reactions to the Toxics Release Inventory Data. Journal of Environmental Economics \& Management, 28, 98-113. https://doi.org/10.1006/jeem.1995.1007

[16] Klassen, R.D. and Mclaughlin, C.P. (1996) The Impact of Environmental Management on Firm Performance. Management Science, 42, 1199-1214. https://doi.org/10.1287/mnsc.42.8.1199

[17] Francisco Climent, Pilar Soriano (2011) Green and Good? The Investment Performance of Us Environmental Mutual Funds. Journal of Business Ethics, 103, 275-287. https://doi.org/10.1007/s10551-011-0865-2

[18] Cortez, M.C., Silva, F. and Areal, N. (2009) The Performance of European Socially Responsible Funds. Journal of Business Ethics, 87, 573-588. https://doi.org/10.1007/s10551-008-9959-x

[19] Hongtao, S., Zhen, H. and Ruifang, G. (2014) Research on the Relationship between Environmental Performance and Environmental Information Disclosure. Nankai Management Review, 17, 56-63.

[20] Wenjing, L. and Xiaoyan, L. (2015) Institutional Investors Concerned about the Environmental Performance of Enterprises? From China's Heavily Polluting Industries Listed Companies Empirical Evidence.

[21] Graves, S. and Waddock, S. (1994) Institutional Owners and Corporate Social Performance. Academy of Management Journal, 37, 1034-1046. https://doi.org/10.2307/256611

[22] Wahba, H. (2008) Does the Market Value Corporate Environmental Responsibility? An Empirical Examination. Corporate Social Responsibility \& Environmental Management, 15, 89-99. https://doi.org/10.1002/csr.153

[23] Spicer, B.H. (1978) Investors, Corporate Social Performance and Information Disclosure: An Empirical Study. Accounting Review, 53, 94-111.

[24] Dowell, G., Hart, S. and Yeung, B. (2000) Do Corporate Global Environmental Standards Create or Destroy Market Value? INFORMS.

[25] Rennings, K., Ziegler, A., Ankele, K. and Hoffmann, E. (2006) The Influence of Different Characteristics of the EU Environmental Management and Auditing Scheme on Technical Environmental Innovations and Economic Performance. Ecological Economics, 57, 45-59.

[26] Darnall, N., Jolley, G.J. and Handfield, R. (2008) Environmental Management Systems and Green Supply Chain Management: Complements for Sustainability? Business Strategy \& the Environment, 17, 30-45. https://doi.org/10.1002/bse.557

[27] Nainggolan, Y., How, J. and Verhoeven, P. (2016) Ethical Screening and Financial Performance: The Case of Islamic Equity Funds. Journal of Business Ethics, 137, 83-99. https://doi.org/10.1007/s10551-014-2529-5

[28] Porter, M.E. and Kramer, M.R. (2006) Strategy and Society: The Link between Competitive Advantage and Corporate Social Responsibility. Harvard Business Review, 84, 78.

[29] Ghoul, S.E. and Karoui, A. (2016) Does Corporate Social Responsibility Affect Mutual Fund Performance and Flows? Journal of Banking \& Finance, 77, 53-63.

[30] Carhart, M.M. (1997) On Persistence in Mutual Fund Performance. Journal of Finance, 52, 57-82. https://doi.org/10.1111/j.1540-6261.1997.tb03808.x 
[31] Mallin, C.A., Saadouni, B. and Briston, R.J. (1995) The Financial Performance of Ethical Investment Funds. Journal of Business Finance \& Accounting, 22, 483-496. https://doi.org/10.1111/j.1468-5957.1995.tb00373.x

[32] Gregory, A., Matatko, J. and Luther, R. (2010) Ethical Unit Trust Financial Performance: Small Company Effects and Fund Size Effects. Journal of Business Finance \& Accounting, 24, 705-725. https://doi.org/10.1111/1468-5957.00130

[33] Luther, R.G. and Matatko, J. (1994) The Performance of Ethical Unit Trusts: Choosing an Appropriate Benchmark. British Accounting Review, 26, 77-89. https://doi.org/10.1006/bare.1994.1007 